Clemens Özelt

\title{
Establishing Evidence through a Shift in Viewpoint
}

\author{
Galileo's Dialogues as a Genre Model in Texts of the Weimar \\ Republic (Einstein, Brecht, Döblin)
}

Wie die Erde selbst drehte sich unsre Unterhaltung um die Sonne.

(Heinrich Heine)

\begin{abstract}
The paper examines dialogues and reflections on dialogues by $\mathrm{Al}$ bert Einstein, Bertolt Brecht and Alfred Döblin at the beginning and the end of the Weimar Republic, analyzing the aesthetics and the history of the genre in its sociohistorical context. The results can be outlined in the following four theses:

1) During the Weimar Republic, dialogue becomes a productive medium of self-understanding for scientific and social modernity, making it possible to coordinate the dominant discourses of politics, literature and physics. 2) Referring to the Renaissance dialogue, historicizing becomes an important interdiscursive method, providing an insight into the relations of different social systems in historical distance. 3) Dialogue, in the Galilean tradition, offers experimental experiences that effect shifts of paradigm by changing points of view. 4) As an ideologically versatile form, dialogue can structure various societal transitions.
\end{abstract}

\section{Introduction: Galilean turns}

Encountering opposition, ideas have to take detours; arguments shift their perspective, stories change their genre, texts their publishers. ${ }^{1}$ A notable example of this is one of the best-selling books in history, the Manifesto of the Communist Party. For about 25 years, the manifesto, published in 1848 in London, found few readers in Germany, Marx' and Engels' country of origin. In his introduction to the Modern Edition of The Communist Manifesto, Eric Hobsbawm shows how the distribution of the text was far from straightforward:

1 The complete article was translated from the German by Sarina Tschachtli.

Ә Open Access. ( 2021 Clemens Özelt, published by De Gruyter. (c) BY-NC-ND This work is licensed under the Creative Commons Attribution-NonCommercial-NoDerivatives 3.0 License. 
[T] he treason trial of the German Social-Democratic leaders, Wilhelm Liebknecht, August Bebel and Adolf Hepner in March 1872 gave the document unexpected publicity. The prosecution read the text of the Manifesto into the court record, and thus gave the SocialDemocrats their first chance of publishing it legally, and in a large print run, as part of the court proceedings.

(Hobsbawm 1998, 6)

In the German empire of 1872, the court was a confined area where freedom of speech could be exercised legally. In Jürgen Habermas' words, the court was used as an institution of the public sphere [Öffentlichkeit] where reason "was to be realized in the rational communication of a public consisting of cultivated human beings" (Habermas 1991, 35). Forty-five years later, another successor of Marx and Engels used the court anticipating a democratic public sphere: Friedrich Adler, the physicist and later Secretary of the Labor and Socialist International. He was prosecuted for the murder of the Austrian Minister-President Stürgkh in 1917. In his plea, Adler recounts his previous history of political engagement; how he lacked a public sphere for his concerns and had to use historical camouflage or other disguises. Adler uses the court as a public forum to find support for his political position, a position that presupposes an entirely different view of the world, as he asserts twice. He does so not by comparing himself to Liebknecht and Bebel, and not even to Marx and Engels. Instead, the physicist represents himself as Galileo Galilei facing the Roman Inquisition (Adler 1919, 51-52). In 1933, Georgi Dimitrov, later Secretary-General of the Comintern, invoked the same scene in front of the Reichstag Fire Trial (the Leipzig Trial). Referring to the former democratic public sphere, Dimitrov insists on the (political) power of a truth made public. He presents the anticipated triumph of socialism as knowledge-based, more than Adler even, with his speech culminating in a final reference to Galileo: Dimitrov was led away with the concluding words, "yet it does move" - the very same sentence that Galilei is said to have muttered after he renounced the Copernican theory to the Roman inquisition (cf. Drake 1978, 353-358, 356). Again, a textual disguise was necessary for wider distribution; the speech was distributed as a "camouflage publication" Why Not a Musical Instrument? [(Tarnschrift): Warum nicht ein Musikinstrument?] (Dimitroff 1934, 27-28; cf. Gittig 1972, 116).

In both scenes, Galileo is called on as a witness to signal a knowledgebased triumph. His triumph is hindered only momentarily by the asymmetrical speech situation, but it will ultimately be ensured when a new public sphere is established. Adler and Dimitrov trusted "in reason's gentle tyranny over people” (Brecht 1980, 29), as Brecht's Galileo phrases it. In this manner, these trials illustrate a specific political self-understanding, but they also frame the time period that will be examined in the following. Set at the beginning and the end of the Weimar Republic, both of these trials involve representatives of the labor 
movement, and in both cases the hearings developed into defenses of republican values. For this purpose, not only is Galileo called on as a witness, Adler and Dimitrov also stage a court case that references the famous inquisition of Galileo, relying on the form of the dialogue and thus illustrating its specific value. The two socialists both imagined Galileo losing the trial, yet establishing a new worldview. Thus, both of them strove to enact rhetorically a change of viewpoint that re-contextualized the prosecution not legally (before the court), but politically (before the public) - and by making it public in writing.

This principle of changing viewpoints is constitutive for Galileo's dialogues: the evidence established is not a question of seeing something clearly or plainly (this is the role Galileo's Aristotelian Simplicio assumes), but of seeing something differently, re-contextualizing the first impression. Changing a view by using a shift in viewpoint, the dialogues imply progress: they are not only about seeing differently, but also about seeing more and better. According to Hans Blumenberg, these are experimental experiences rather than immediate visual or sensual impressions, and they belong to Galileo's basic epistemological principles. He illustrates this with the following sequence from the Discourses and Mathematical Demonstrations Relating to Two New Sciences [Discorsi]. Salviati, also a protagonist of the Dialogue Concerning the Two Chief World Systems and Galileo's representative, states: "See now the power of truth [la forza della verità]; the same experience which at first glance seemed to show one thing, when more carefully examined, assures us of the contrary" (Blumenberg 1987, 408-409). This process of insight accounts for the form of the dialogue. In his preface to the Dialogue, Galileo argues as follows:

I have thought it most appropriate to explain these concepts in the form of dialogues, which, not being restricted to the rigorous observance of mathematical laws, make room also for digressions which are sometimes no less interesting than the principal argument.

(Galilei 1953, 6)

This passage addresses two key issues of this analysis. Firstly, it mentions the usefulness of detours in cognitive processes, as they necessitate a change of viewpoint. Secondly, it reveals Galileo's aspirations to affect public opinion in its use of Italian as a common language (and in avoiding the use of mathematical formulae). Thus, the passage indicates how the dispute with the authorities, referenced by the first sentence of the preface (Galilei 1953, 5), is used to reach a significantly broader public. Therefore, the phrase eppur si muove becomes representative of a process of understanding in a shift of viewpoint that is quintessential to the dialogues. 
As the inquisitional scene influences the political processes of the Weimar Republic, the Dialogues influence the production of texts interlinking physics, politics and literature.

The genre even experienced a revival in its original discipline, physics. Albert Einstein, who knew Friedrich Adler from Zurich, makes use of it in his 1918 Dialogue about Objections to the Theory of Relativity [Dialog über Einwände gegen die Relativitätstheorie]. After his Relativity: The Special and the General Theory [Über die spezielle und die allgemeine Relativitätstheorie], Einstein used the genre not only as a way to popularize scientific concepts, but also to produce textual effects that call attention to "the purely fictitious character of the fundamentals of scientific theory" (Einstein 1935, 134), as he explains in The Method of Theoretical Physics [Zur Methodik der theoretischen Physik].

Bertolt Brecht, fascinated by Dimitrov's speech in court, found himself in a similar situation in the 1930s. Convinced of the validity of Marxist theory, he found that its fundamental premises, such as exploitation, were not part of the working class's self-understanding: not unlike heliocentrism, class relations are not immediately visible, but rely on a specific point of view. The genre characteristics outlined prompted Brecht to model his theoretical text, The Messingkauf Dialogues [Der Messingkauf], on Galileo's Dialogue. Furthermore, this form of scholastic dialogue characteristic for the discourse of physics influences Brecht's texts of the late 1930s: the Einstein-dialogue in Fear and Misery of the Third Reich [Furcht und Elend des Dritten Reichs], Refugee Conversations [Flüchtlingsgespräche], and of course the Life of Galileo [Leben des Galilei]. As such, they also contribute to Brecht's large-scale project of creating a theatre of the scientific age.

Whereas Brecht used the historical situation of upheaval for utopian projects, Alfred Döblin took the new world order as an opportunity to trace a dystopian development underneath the narrative of scientific progress. Döblin, who had already dismissed Einstein's book on relativity in 1923, ended his extensive narrative of modern history, Amazon, with a final judgment instead of a world revolution. The novel identifies the harmful potential of the natural sciences and the disruptive developments they caused, ultimately to make a case for religious reform. His work can thus be said to find a consistent continuation after 1945 in the reactivation of the religious dialogue in Immortal Man [Der unsterbliche Mensch] and The Battle with the Angel [Der Kampf mit dem Engel].

We might ask why texts by authors as diverse as Einstein, Brecht and Döblin refer back to Galileo's Dialogue, which was published some three hundred years earlier. This might be better understood in the context of a socio-cultural phenomenon of identity formation around 1900 that has been termed Renaissancism and constitutes a historical background for the texts to be examined. In his study 
analyzing dramas of the period, Gerd Uekermann observes that, somewhat surprisingly, the German middle class found the Florence of the Medici a suitable model of identification (Uekermann 1985, 282). He traces this self-reflection in historical costume, as he terms these processes of self-understanding ("Selbstbespiegelung im historischen Kostüm," Uekermann 1985, 282), back to the belated reception of Jacob Burckhardt's The Civilization of the Renaissance in Italy, which was influenced by none other than Friedrich Nietzsche. The Renaissance plays that Uekermann examines became, he argues, a compulsory exercise for young dramatists at the turn of the century. They also show a very selective perception of Burckhardt's delineation of the era, as Uekermann demonstrates conclusively:

Neither the appropriation of the legacy of antiquity nor the era's scientific and cultural achievements are the concern of Renaissancism, but rather the theme of great, powerful, individually shaped personalities. Most representatives of the genre concentrate not on Burckhardt's ideal of the 'uomo universale e singolare,' of the universally educated individual, but on a type that is treated rather marginally in the 'culture of the Renaissance:' the ruthless man of action and violence, acting beyond all ethical and moral liabilities, the ingenious virtuoso of crime, the perverted outgrowth of the cult of personality. ${ }^{2}$

(Uekermann 1985, 54)

This cult is embodied in Cesare Borgia (Uekermann 1985, 60) who becomes an exemplary figure of reference. Politically, the man of violence [Gewaltmensch] opposes organized forms of government such as democracy and works against the rising labor movement. According to Uekermann, the heyday of Renaissancism ends as World War I breaks out and the young Weimar Republic is established after the abdication of Wilhelm II in 1918.

In the period between the world wars, however, another form of Renaissancism can be observed, I would argue: one that rectifies the selective perception of the era and adapts to its changing social conditions. This second Renaissancism is concerned with scientific achievements and a collective effort at consensus in a public sphere. It is in this socio-historical context that Galileo Galilei

2 Transl. by ST. "Weder die Aneignung des antiken Erbes noch die wissenschaftlichen und kulturellen Errungenschaften der Epoche sind für den Renaissancismus von Interesse, sondern in erster Linie das Thema der großen, kraftvollen, individuell ausgebildeten Persönlichkeiten. Und die Mehrzahl der Vertreter des Genres konzentriert sich dabei nicht auf Burckhardts Ideal vom 'uomo universale e singolare,' vom umfassend gebildeten Einzelmenschen, sondern auf einen Typus, der in der 'Kultur der Renaissance' eher peripher behandelt wird: den skrupellosen, jenseits aller ethischen und moralischen Verpflichtungen rücksichtslos handelnden Tat- und Gewaltmenschen, den genialen Virtuosen des Verbrechens, den pervertierten Auswuchs des Persönlichkeitskultes” (Uekermann 1985, 54). 
surfaces as an ideal figure of identification, and the dialogue as a republican genre. The strongest impulses are to be found on the margins of the era: after the declaration of the Republic (1918) and during the first years of the exile (after 1933, when many intellectuals were forced to flee Nazi Germany), in the course of extensive and intense intellectual discussions of the short democratic interlude of the Weimar Republic.

\title{
2 Albert Einstein: A relativistic turn
}

That the Dialogue Concerning the Two Chief World Systems epitomizes the interlinking of physics, politics and literature can be substantiated further by the preface that Albert Einstein wrote for the edition of the text published by Stillman Drake in 1953. Three years before his death, the well-established scientist outlines his own understanding of the history of science by writing the following:

Galileo's Dialogue Concerning the Two Chief World Systems is a mine of information for anyone interested in the cultural history of the Western world and its influence upon economic and political development.

\begin{abstract}
A man is here revealed who possesses the passionate will, the intelligence, and the courage to stand up as the representative of rational thinking against the host of those who, relying on the ignorance of the people and the indolence of teachers in priest's and scholar's garb, maintain and defend their positions of authority. His unusual literary gift enables him to address the educated men of his age in such clear and impressive language as to overcome the anthropocentric and mythical thinking of his contemporaries and to lead them back to an objective and causal attitude toward the cosmos, an attitude which had become lost to humanity with the decline of Greek culture.
\end{abstract}

In speaking this way I notice that I, too, am falling in with the general weakness of those who, intoxicated with devotion, exaggerate the stature of their heroes.

(Einstein 1953, vii)

The text that follows shows Einstein's preference for a historiography of science very much based on individual achievement. Einstein outlines Galileo as a representative Renaissance man in Burckhardt's sense: as a lone genius fighting not only authorities but also the public. (In this regard, his understanding of Galileo differs significantly from Brecht's.) As a comprehensively educated Renaissance man, Galileo advocates not only a theory, but also a worldview. In doing so, he relies decisively on his "unusual literary gift," "his extraordinary literary talent" (Einstein 1953, xi), to which Einstein refers repeatedly. In his 
anthology The World as I See It, composed during the first years of his exile, Einstein reinforces this individualistic notion of the era. In Society and Personality, he traces the "brilliant flowering in the Italian Renaissance" back to "the liberation and comparative isolation of the individual" (Einstein 1935, 9); in Fascism and Science, a letter to the Italian Minister of State, Alfredo Rocco, he goes so far as to attribute the prospering of the Renaissance to "the martyr's blood of pure and great men" (Einstein 1935, 31).

The phenomenon of a change of viewpoint can be explored further in Einstein's conclusion, where he counters the common view of Galileo as an empiricist quite forcefully. He writes: "There is no empirical method without speculative concepts and systems; and there is no speculative thinking whose concepts do not reveal [verraten], on closer investigation, the empirical material from which they stem" (Einstein 1953, xvii). The so-called betrayal [Verrat] of empirical knowledge indicates the importance of the thought experiment in Einstein's scientific self-understanding (which he uncovers, so to speak, in historical garment).

Einstein strove for continuity in his history of science, particularly with regard to classical mechanics. He observes how dialogue provokes thought experiments and a change of viewpoint in Galileo's text, and he reverts to this effect in his Dialogue about Objections to the Theory of Relativity in 1918. This short text published in Naturwissenschaften does not hold a key position in Einstein's body of work, but it is part of a broader strategy to gain public resonance and recognition for the theory of relativity. Similarly to Galileo, he used this textual format when debating scientific authorities, as for example the Nobel Laureate in physics of 1905, Philipp Lenard. (Einstein received his Nobel Prize only four years after the dialogue's publication, in 1922.) The conversation between the Relativist and the Criticus echoes the dispute about the establishment of a system of coordinates, but this time in the context of the general theory of relativity. The Criticus uses an example that Lenard proposed elsewhere. He states that with good common sense (cf. Hentschel 1990, 74-91), the victims of a train crash would be well aware that it must have been the train, not the environment that stopped with a jar. The Relativist answers in Galilean manner:

The following counterexample will show how inadvisable it is to appeal to so-called "common sense" as an arbiter in such things. Lenard himself says: so far no pertinent objections have been found to the validity of the special principle of relativity (i.e., the principle of relativity between uniformly translatory motions of coordinate systems). The uniformly moving train could as well be seen "at rest" and the tracks, including the 
landscape, as "uniformly moving." Will the "common sense" of the locomotive engineer allow this? He will object that he does not go on to heat and grease the landscape but rather the locomotive, and that, consequently, it must be the latter whose movement shows the effect of his labor. ${ }^{3}$

(Einstein 2002, 47)

In the Relativist's opinion, common sense could also suggest that the locomotive's engine needs lubrication, but not the landscape. The principle remains the same: The change of viewpoint is not a question of new empirical data or about seeing something else, but about seeing something differently. The evidential value of the change of view is established by the shift of the standpoint, in its re-contextualization. Lenard's common sense is challenged in the dialogue, using a thought experiment to outdo and polemically reject his position, similar to Simplicio's empiricism in Galileo's text.

\section{Bertolt Brecht: A socialist turn}

The history of the German Physics [Deutsche Physik] shows that the confrontation of Einstein and Lenard was more than an episode in the history of science (cf. Beyerchen 1977): it became a political matter. During the first years of his exile, Bertolt Brecht dedicated the short scene The Physicists [Physiker] in Fear and Misery of the Third Reich to the interacting fields of science and politics. It has only recently been discovered that Brecht contacted Einstein shortly after and sent him a first draft of his Life of Galileo. In a short reply, Einstein thanked him for the drama and praised the apt representation of Galileo's personality and the contemporary relevance of the historical drama: "the strong relationships to the political problems of the present” (Wizisla 2005, 350). ${ }^{4}$

3 "Wie wenig es aber angezeigt ist, in solchen Dingen den sogenannten 'gesunden Verstand' als Schiedsrichter anzurufen, zeigt folgendes Gegenbeispiel. Lenard selbst sagt, es hätten sich gegen die Gültigkeit des speziellen Relativitätsprinzips (d. h. des Relativitätsprinzips bezüglich gleichförmiger Translutationsbewegung [sic] der Koordinatensysteme) bisher keine zutreffenden Einwände erheben lassen. Der gleichmäßig fahrende Zug könne ebensogut als 'ruhend,' das Geleise samt der ganzen Gegend als 'gleichförmig bewegt' angesehen werden. Wird dies der 'gesunde Verstand' des Lokomotiv-Führers zulassen? Er wird einwenden, daß er doch nicht die Gegend unausgesetzt heizen und schmieren müsse, sondern die Lokomotive, und daß es dementsprechend die letztere sein müsse, in deren Bewegung sich die Wirkung seiner Arbeit zeige” (Einstein 1918, 701).

4 Transl. by ST. “die starken Beziehungen zu den politischen Problemen der Gegenwart” (Wizisla 2005, 350). 
This political Renaissancism concludes a long-term development in Brecht's work. During the first years of the Weimar Republic, Brecht's texts are influenced by the reception of Burckhardt at the turn of the century. In his notebooks from 1920, he mentions Burckhardt's Civilization of the Renaissance in Italy for the first time (Brecht 2014, 452-453; cf. Gerz 2002, 55). Shortly after, The Death of Cesare Malatesta [Tod des Cesare Malatesta], a short story written in 1924, also reflects this Renaissancism. In it, Malatesta is turned into a victim of the Renaissance character Francesco Gaja, “a man famous for his elegant way of life and utter nastiness” (Brecht 1983, 49). Gaja wages an elaborate war to revenge insulted relatives. The siege that is the culmination of the story is described as a dreadful theater of insight: “The siege lasted three weeks. Gaja's intention, and the point of his jest, was to give the besieged man enough time to review his whole life and find where the rotten spot lay" (Brecht 1983, 52). Politics is reduced to individual revenge; lifestyle and refinement are perfected to serve torture. Yet, the epistemic potential of this theater is undermined by the text, with the narrator and chronicler finally noting about Malatesta: "It seems certain that up to and including his last hour he did not know why all this was happening, and certain that he did not ask" (Brecht 1983, 52). A comparable constellation can be found in The Life of Edward II of England [Leben Eduards des Zweiten von England], Brecht's adaption of a historical tragedy by Marlowe (cf. Gaston 2003). It stages a dynamic of revenge and counter-revenge, multiplying the Malatesta-plot. Furthermore, the text recalls the genre of the Renaissance dialogue and drew the interest of none other than Alfred Döblin, who reviewed the play in the Leipziger Tageblatt on 21 December 1924 (Döblin 1990, 432-434 and 516).

Characteristics of the turn of the century Renaissancism are apparent in these texts from 1924. Typically for Brecht, his work reflects the English and Italian Renaissance simultaneously; yet, a shift of emphasis can be observed around 1938. He again writes short stories about the Renaissance, such as The Experiment [Das Experiment], (Brecht 1983, 153-162) and The Heretic's Coat [Der Mantel des Ketzers], (Brecht 1983, 162-170). However, rather than centering on a Gewaltmensch, these revolve around scientists. Thus, Christopher Marlowe and Cesare Borgia, who lends his name to Cesare Malatesta, are replaced by Francis Bacon and Giordano Bruno, followed by Shakespeare and Galileo. Brecht's play Life of Galileo (first written in 1939) without doubt represents the best-known recourse to the Renaissance in Brecht's body of work. The play originates in the same period in which he developed a theory of theater in The Messingkauf Dialogues. On 12 February 1939, Brecht notes in his journal: "a lot of theory in dialogue form the messingkauf dialogues (spurred to use this form by galileo's dialogues)" (Brecht 1993, 20). Similar to the Dialogue Concerning the Two Chief World Systems, the disputants meet on four different nights. The 
participants - the Philosopher, the Actor, the Actress, the Dramaturg, and the Electrician - discuss the current challenges, tasks and aims of the theater. Brecht's Messingkauf remained a fragment. Only parts of it were published or used for other texts, such as A Short Organum for the Theatre [Kleines Organon für das Theater]. Thus, there is no cohesive, authorized version of the dialogue.

The Messingkauf Dialogues are exemplary in their use of dialogue to advocate a theory of theater, as they act out and thus clearly display the process. Brecht outlines the essential concerns in a theoretical paratext to the dialogues (as a theory before theory, so to speak), in his Second Appendix to the Messingkauf Theory:

The self-evident - i.e. the particular shape our consciousness gives our experience - is resolved into its components when counteracted by the A-effect [alienation effect] and turned into a new form of the evident. An imposed schema is broken up here. The individual's own experiences correct or confirm what he has taken over from the community. The original act of discovery is repeated.

The contradiction between empathy and detachment is made stronger and becomes an element in the performance.

Historicizing involves judging a particular social system from another social system's point of view. The standpoints in question result from the development of society. Note: Aristotelian dramaturgy takes no account (i.e. allows none to be taken) of the objective contradictions in any process. They have to be changed into subjective ones, located in the hero.

(Brecht 1977, 102-103)

The phenomenon I have endeavored to describe, of how a shifting of viewpoint establishes evidence, can also be understood in the familiar terms of the alienation effect. In both instances we find a change of perspective or a re-contextualization; an ordinary phenomenon attains "a new form of the evident" when habitualized structures of understanding dissolve. The historicizing mentioned in point three plays a central role in this context as it references the interconnectedness of cultural subsystems (in the case of Galileo: physical and societal systems). Point two indicates how the process of comprehension becomes an "element in the performance;" it can take place in public entertainment spaces such as the theater. In the form of a sensuous experience, these processes of comprehension can reach a wide public, something a reference book or scientific theory cannot replace.

Thus, according to Brecht, literature has to be understood in terms of its connectedness with other societal subsystems. What follows from this systematized understanding of literature is, interestingly, that the Messingkauf becomes a theory of a process of social interrelation, a process in which elements gain their specific functions and positions in mutual adaption and exchange with 
one another. In a corresponding passage, Brecht characterizes the relationship between the sciences and societal interests as follows:

It's because people know so little about themselves that their knowledge of nature is so little use to them. They know why a stone falls in a particular way when you throw it, but why the man throwing it acts in that particular way is another matter. Thus they can cope with earthquakes, but not with their fellows. Every time I leave this island I'm frightened that the boat may go down in a storm. But I'm not frightened so much of the sea really as of the people who might fish me out.

(Brecht 1977, 31)

This passage is dialogic insofar as the three images are presented in double views. They imply diverging levels of insight between intellectual power over nature and societal control over such power. It is this discrepancy that, ultimately, nourishes the concerns of what can be termed a societal or socialist turn. This understanding of social functions and societal emplacement affects both scientific discoveries and artistic intention. In conversation with the Actor, the Philosopher comments on the role of the Author (who, programmatically, remains silent throughout the Dialogues): “Oh, I'd say the writer's intentions were only of public interest when they provoked the public's interest” (Brecht 1977, 38).

The shifting of perspective is a fundamental structure of the Messingkauf and crucial to the process of understanding, which is also delineated more clearly by the multiplication of viewpoints. Whereas the passage above emphasizes the societal impact of a change of perspective, other passages develop the change of viewpoint based on a phenomenology of seeing. Yet, the shifting of perspectives and the social standpoint can be understood as aspects of one and the same process of understanding:

To describe art as the realm of the beautiful is to set about it in too passive and allembracing a way. Artists deploy skills: that is the first point. What makes artificial things beautiful is the fact of their being skillfully made. [...] Beauty in nature is a quality which gives the human senses a chance to be skillful. The eye is producing itself. That isn't an independent process which stops there. Nor is it one that has not been prepared by other processes, social processes, processes involving other types of production.

(Brecht 1977, 96)

This fragment from the fourth night establishes seeing as a pre-structured as well as a structuring practice, epitomized in the sentence "The eye is producing itself." Aesthetics, politics, and science presuppose and determine each other in intricate interrelations. In Brecht's approach, the participants in the conversation are supposed to consider and coordinate these diverse interests and connections in a "dialectical twist" at the end of the fourth night (Brecht 1993, 135). With the repetition of these processes of interrelation in the different scenes, a 
method is rendered visible early on, establishing the theatre of the scientific age and negotiating its subject matters in dialogue. The self-reflection of working methods is acted out similarly. A conversation about the thought experiment, which has been established in the examined dialogues, illustrates this method further. Again, Brecht historicizes in this scene, when the dialogue explicitly refers to an earlier era and at the same time implicitly represents his own historical standpoint:

THE PHILOSOPHER: The Globe Theatre's experiments and Galileo's experiments in treating the globe itself in a new way both reflected certain global transformations. The bourgeoisie was taking its first hesitant footsteps. Shakespeare could never have tailored the part to fit that short-winded character actor of his if the feudal family hadn't just collapsed. Hamlet's new bourgeois way of thinking is part of Hamlet's sickness. His experiments lead straight to disaster.

THE DRAMATURG: Not straight. Zigzag.

THE PHILOSOPHER: All right; zigzag. In a sense the play has the permanence of something makeshift, and I agree that that probably has to be resolved if we're to preserve it. (Brecht 1977, 60-61; emphasis in original)

Enacted in the alternating of the speakers, the principle of understanding becomes, to use Brecht's words, an element in the performance. In the dialogue, the dramaturg demonstrates that the change of viewpoint is inherently erratic, not linear. The course of understanding is not straight, but zigzag: scientia facit saltus. It does not lose itself in uncertainty; rather, it sharpens its subject matter in the multiplicity of perspectives, resulting in the "permanence of something makeshift." For Brecht, dialogue is not just, as Musil feared, a "polygon of possible opinions" ["Polygon der möglichen Meinungen"] (Musil 2009) that stands in the way of progressive specification. In the conciseness of his interjection, the dramaturg illustrates the ease of this turning point.

Brecht consistently coordinates the discourses of physics, politics and literature on multiple levels, and in doing so accepts the imprecisions of analogies. By experimenting, he draws connections that are at odds with the selfcontained spaces of Hamlet as a drama, of the Globe Theater as a public sphere, of Galileo's science and of his own present. Thus, his use of dialogue becomes an encompassing principle of construction, not just as an alternating of speakers, but as an exchange of eras, cultures, languages and institutions, people, senses, perceptions and even single words: not straight, zigzag. 


\section{Alfred Döblin: A religious turn}

Brecht understands dialogue as a distinct genre on the one hand, but also uses it as an instrumental form on the other hand, which significantly influences his reorganization of the theater. Both of these aspects can also be discerned in Alfred Döblin's work. He, too, strives to establish dialogue as a genre in itself, yet also uses it as a non-narrative element to diversify his prose. Put simply, both writers, Brecht in his plays and Döblin in his epic prose, approach the phenomenon from two different angles.

An example of dialogization in epic form is the prose text The Influence of Celestial Bodies on the German Theatre [Der Einfluß der Gestirne auf das deutsche Theater], published in 1924. Apart from short situational sketches, the text consists solely of conversational sequences between the two astronomers L. and O. Both being physicists from Potsdam, they embark on a journey to Mexico to see the "Einstein effect" ["Einsteineffekt"] (Döblin 1990, 434) during the solar eclipse. The dialogue opens with the younger colleague 0 . wearily observing the discrepancy between effort and achievement. First, he contrasts the preparations that lasted for months with the ten to fifteen minutes of observation time; second, he compares the small spatial deviation predicted in the telescope with the geographic extensiveness of the expedition; third, he laments the discrepancy between the investment of dozens of "Spezialmenschen" (Döblin 1990, 434), as the text calls them, and the indifference of society to the discovery.

This opening is reminiscent of the polemics that Döblin published a year earlier in the Berliner Tageblatt, and later in Self Over Nature [Das Ich über der Natur], intending ironically to reveal the irrelevance of the theory of relativity to society. In this dialogue between the astronomers, however, the theory of relativity is a vantage point used to diagnose a crisis that affects not only physics but also other societal subsystems, such as politics and the arts: "at the theater, no one knows anymore what it is there for" (Döblin 1990, 440), ${ }^{5}$ as one of the characters, namely the older physicist, puts it. This enumeration of societal subsystems is further pursued up to a point of change typical for Döblin's dialogues: he adds religion as a fourth dimension to the triad physics-politics-literature. The older physicist argues:

This is indeed curious: people say that the major religions have lost their meaning, that they have become churches. To put it bluntly: The spirit has gone to hell. Yet they don't say this about art or the theater. Why not, colleague? The ocular is not adjusted properly;

5 Transl. by ST. “am Theater weiß kein Mensch mehr, wozu es da ist” (Döblin 1990, 440). 
they don't see. Too close or too far away. Imagine a giant arriving at the Gulf of Mexico with us and using our ship as a foot-soaking tub. This would be a misuse of our ship, which was made for traveling. Yet the giant sticks his feet into it, and it works. There once used to be an art, as there used to be peoples, tribes, communities. There used to be a proper theater. And then the giant came. I also don't want to talk about the economy, about politics. The giant takes the theatre, everything remains as it was, and a few centuries later no one remembers what this grandiose, festive, wonderful piece of furniture really was. ${ }^{6}$

(Döblin 1990, 440-441)

The same basic structure as in Einstein and Brecht can be seen here: Not-seeing ["sie sehen nicht"] leads to an experiment of thought ["Denken Sie sich"]. The jump in the narration (from ship to wash-tub) entails a shift in perspective that introduces the dimension of time into the image. As with Brecht, this historical perspective enables us to understand social systems in shifting functional contexts. Without the detour of the narration (introducing a timeline) and its images (introducing the ship in relation to sailors and giants), this would not be evident: the ship's function cannot be deduced from the object itself.

If we believe Döblin's claim that he has indeed read Einstein's Relativity: The Special and the General Theory dozens of times, in parts and in its entirety in 1923 (Döblin 1928, 18), then we can safely assume that Einstein inspired the text's effect. In a short preliminary remark, Einstein writes about the aesthetic potential of transgressing dimensions:

The non-mathematician is seized by a mysterious shuddering when he hears of 'fourdimensional' things, by a feeling not unlike that awakened by thoughts of the occult [ein Gefühl, das dem vom Theatergespenst erzeugten nicht unähnlich ist]. And yet there is no more common-place statement than that the world in which we live is a four-dimensional space-time continuum. ${ }^{7}$

(Einstein 1960 [1916], 55)

6 Transl. by ST. "Das ist nämlich das Kuriose: von den großen Religionen sagen die Leute, sie haben ganz ihren Sinn verloren, sie sind Kirchen geworden. Zu deutsch: Der Spiritus ist zum Deibel. Von der Kunst, oder aber dem Theater, sagen sie es nicht. Warum wohl nicht, Kollege? Schlechte Einstellung des Okulars; sie sehen nicht. $\mathrm{Zu}$ dicht vorne oder zu weit ab. Denken Sie sich, ein Riese findet sich im Meerbusen von Mexiko zusammen mit uns ein und benützt unser Schiff als Fußbadewanne. Das wäre ein Mißbrauch unseres Schiffes, das zum Fahren eingerichtet wurde. Aber der Riese steckt seine Füße hinein, und es geht. Da hat es mal eine Kunst gegeben, wie es auch mal richtige Völker, Stämme, Gemeinschaften gegeben hat. Es gab mal ein richtiges Theater. Und dann ist ein Riese gekommen. Auch ich will nicht von der Wirtschaft, der Politik sprechen. Der Riese nimmt das Theater, alles bleibt wie vorher, nach ein paar Jahrhunderten weiß niemand mehr, was dies grandiose feierliche herrliche Möbel eigentlich war" (Döblin 1990, 440-441).

7 "Ein mystischer Schauer ergreift den Nichtmathematiker, wenn er von 'vierdimensional' hört, ein Gefühl, das dem vom Theatergespenst erzeugten nicht unähnlich ist. Und doch ist 
The phantom of the theater [“Theatergespenst"] vs. the theater's staff, four vs. three dimensional space, the historical timeline vs. the present - all these shifts of perspectives are informed by the same logic of progress (even though they pursue different aims). Einstein found them in the texts of Helmholtz and Poincaré - as an interrelation of body and shadow (illustrating the dimensional jump in analogy). Ultimately, we can trace this figure of thought back to the most influential political and epistemological dialogue of the Western world: Plato's The Republic [Politeia] and the Allegory of the Cave.

Döblin's dialogue from 1924 provides the basic model for his Amazon Trilogy, a text he worked on during his Paris exile from 1935 on. The novel tells the extensive story of the European colonization of South America. At the beginning of the second volume's fifth book historical turning point [Zeitenwende], the novel refers to the scientific discoveries in Europe, usually at the beginnings of chapters. The simultaneity of colonization and scientific discovery invites a comparison between nature's subjection to unitary laws and the subjugation of the indigenous peoples to the colonial masters, reflecting critically on the Renaissance era (cf. Pfanner 2003). Gradually, the Jesuits' religious experiment in South America and the physical experimentation in Europe come into conflict. Subtly indicated at first, the confrontation becomes a conflict in dialogue at the beginning of the third volume The New Jungle [Der neue Urwald], extending the historical novel's present to the Weimar Republic. The Polish mythical figure Twardowski calls the physicists Copernicus, Galilei and Giordano Bruno to a last judgment in St. Mary's Basilica in Cracow, confronting them, from a historical distance, with the sociocultural consequences of the insinuated changes in worldview. As a reference to the Prologue in Heaven in Goethe's Faust, this dialogue is the first of two parts of a conversation between Twardowski and the physicists that frames and contextualizes the stories set in the Weimar Republic (Döblin 1988, 8-20 and 110-120).

The resurrection of the three physicists turns the conversation into a Dialogue of the Dead in the tradition of Lucian. To begin, Twardowski, a figure not unlike Faust, holds the Cracovian Nicolaus Copernicus accountable for the physical worldview of the present day; the text calls Copernicus the root of all evil ["Wurzel alles Übels"] three times. Galileo Galilei and Giordano Bruno are later brought forward as accused, representing the historical reception of the Copernican worldview intricately linked with the subsequent break with religion. As we can see, the conversation hinges once again on the contextualization of seeing.

keine Aussage banaler als die, daß unsere gewohnte Welt ein vierdimensionales zeiträumliches Kontinuum ist” (Einstein 2009 [1916], 36). 
The novel undercuts the primacy of seeing in the dialogue between Copernicus and Twardowski, alluding to the skeletons of the dead:

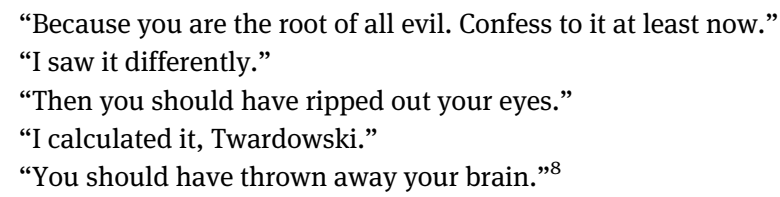

(Döblin 1988, 10)

Seeing and calculation designate the base operations of modern sciences. Galileo's unwilling retraction before the Roman Inquisition, which was expressed most concisely in "yet it does move," is acknowledged 300 years later as a firm conviction. Galileo now sees more than he saw in his telescope; he grasps the anthropological consequences of the Copernican discoveries and retracts, referencing the sequence of dialogue cited above, with the following words: "I repent. I should have ripped out my eyes, thrown away my brain" (Döblin $1988,14)^{9}$

Since Giordano Bruno does not bow to Twardowski's accusations as promptly as Galileo, he is given more narrative space (the two chapters are called Herr von Twardowski and Giordano Bruno accordingly). Bruno assumes a mediating position between natural sciences and mysticism of nature. The intertextual references that the novel makes to Bruno's dialogues, such as On the Infinite Universe and Worlds or The Ash Wednesday Supper, intricately and aptly integrate into the trilogy's narrative structure. In The Ash Wednesday Supper, Bruno's Copernican Dialogue, Teofilo critically comments on the colonization of South America: "The helmsmen of explorations have discovered how to disturb everybody else's peace, [how to] violate the native spirits of the regions [...]. They showed new ways, instruments, and arts for tyrannizing and murdering each other" (Bruno 1977, 88-89).

Bruno's alter ego announces a Zeitenwende, a change of times that will see the instruments and methods of tyrannizing turn against the ones who invented them. Döblin's Der neue Urwald also relates to this. The intertextual references show how Döblin attempts to disclose a tradition in the Renaissance that is

8 Transl. by ST. “'Weil du die Wurzel alles Übels bist. Gesteh es wenigstens jetzt.' / 'Ich habe es anders gesehen.' / 'Dann hättest du dir die Augen ausreißen sollen.' / 'Ich habe es berechnet, Twardowski.' / 'Du hättest das Gehirn wegwerfen sollen”’ (Döblin 1988, 10).

9 Transl. by ST. "Ich bereue. Ich hätte meine Augen herausreißen, mein Gehirn wegwerfen sollen” (Döblin 1988, 14). 
skeptical of the arts for tyrannizing. Teofilo delineates another Renaissance, referring to Bruno: "The Nolan, in order to cause completely opposite effects, has freed the human mind and the knowledge, which were shut up in the strait prison of the turbulent air" (Bruno 1977, 89). Yet again, the dialogue creates a shift of viewpoint, resulting in completely opposite effects.

This tension determines the final dialogue of Döblin's novel. Twardowski gives his skeptical diagnosis of the present a dimension of depth (a fourth dimension) by looking back over the devastations of the past centuries. Following his hymn to the era of the machine that celebrates men as creators (Döblin 1988, 16-19), Bruno gives a different prospect of the Nolan's future. The positions remain irreconcilable:

"I am the conscience of your time. I am given the power to summon you and to bring you to justice."

"Twardowski, you have summoned me too early. Five-hundred years still."10

(Döblin 1988, 118)

This temporal tension is not resolved in the dialogue. Rather, another Zeitenwende is announced, one that puts the historical readers on the crossroads of the future.

\section{Coda: Copernican turns}

After several turns (the relativist, the socialist, and the religious), we finally come back to the Copernican turn with Giordano Bruno. However, we are not coming to a full circle. Rather, an entirely different story of Copernican selfunderstanding can be observed in Döblin's texts. This further attests to the ideological openness of the dialogue as a genre, capable of incorporating all of the shifts examined. We might tie in these varied observations with Hans Blumenberg's understanding of the Copernican Revolution as the most resonating event in the history of metaphors of the modern age:

Enhancement and degradation of men as Copernican readings take likewise what was originally set and discovered not as theoretical truth, not as constructive hypothesis, but as a metaphor. And in fact as an absolute metaphor, in that the Copernican transformation of

10 Transl. by ST. “'Ich bin das Gewissen deiner Zeit. Mir ist die Kraft gegeben, euch zu rufen und zur Verantwortung zu ziehen.' / 'Twardowski, du hast mich zu früh gerufen. Noch fünfhundert Jahre”' (Döblin 1988, 118). 
the cosmos is used as an orientation to answer a question that could never be answered with purely theoretical and conceptual means: the question about the position of men in the world [...]. ${ }^{11}$

(Blumenberg 1965, 127)

From this point of view - re-contextualizing one last time - this short history of the genre of dialogue is a small, form-based building block in a Copernican history of metaphors. It constitutes a productive episode in this history of metaphors that, on the one hand, in a short time assembles many and varied readings and, on the other hand, proves to be a valuable trope of self-understanding that thus sheds light on the cultural field of the Weimar Republic.

\section{Reference List}

Adler, Friedrich. Friedrich Adler vor dem Ausnahmegericht: Die Verhandlungen vor dem §-14-

Gericht am 18. und 19. Mai 1917 nach dem stenographischen Protokoll. Berlin: Paul Cassirer, 1919.

Beyerchen, Alan D. Scientists under Hitler: Politics and the Physics Community in the Third

Reich. New Haven: Yale University Press, 1977.

Blumenberg, Hans. Die kopernikanische Wende. Frankfurt a. M.: Suhrkamp, 1965.

Blumenberg, Hans. The Genesis of the Copernican World. Transl. Robert M. Wallace.

Cambridge, MA: MIT Press, 1987.

Brecht, Bertolt. The Messingkauf Dialogues. Transl. John Willett. London: Methuen, 1977.

Brecht, Bertolt. Life of Galileo. Transl. John Willett. Eds. John Willett and Ralph Manheim.

London: Methuen, 1980.

Brecht, Bertolt. Short Stories 1921-1946. Transl. Yvonne Kapp, Hugh Rorrison, and Anthony

Tatlow. Eds. John Willett and Ralph Manheim. London: Methuen, 1983.

Brecht, Bertolt. Journals. Transl. Hugh Rorrison. Ed. John Willett. London: Methuen, 1993.

Brecht, Bertolt. Notizbücher 4-8 (1920). Eds. Martin Kölbel and Peter Villwock. Berlin:

Suhrkamp, 2014.

Bruno, Giordano. The Ash Wednesday Supper. Transl. and Eds. Edward A. Gosselin and

Lawrence S. Lerner. Hamden: Shoe String Press, 1977.

Dimitroff, Georgi. “Rede vor dem Leipziger Gericht.” Warum nicht ein

Musikinstrument? Münster: Herforth, 1934. 10-28.

Döblin, Alfred. Das Ich über der Natur. Berlin: Fischer, 1928.

Döblin, Alfred. Der neue Urwald. Ed. Werner Stauffacher. Olten: Walter, 1988.

11 Transl. by ST. "Steigerung und Erniedrigung des Menschen als kopernikanische Lesarten nehmen gleichermaßen das, was da ursprünglich gesetzt und entdeckt worden war, nicht als theoretische Wahrheit, nicht als konstruktive Hypothese, sondern als Metapher. Und zwar als absolute Metapher, indem die kopernikanische Umformung des Kosmos zur Orientierung für die Beantwortung einer Frage bestimmt wird, die sich mit rein theoretischen und begrifflichen Mitteln noch nie beantworten ließ: der Frage nach der Stellung des Menschen in der Welt [...]" (Blumenberg 1965, 127). 
Döblin, Alfred. Kleine Schriften 1922-1924. Olten: Walter, 1990.

Drake, Stillman. Galileo at Work: His Scientific Biography. Chicago: University of Chicago Press, 1978.

Einstein, Albert. “Dialog über Einwände gegen die Relativitätstheorie.” Die Naturwissenschaften 48 (1918): 697-702.

Einstein, Albert. The World as I See It. Transl. Alan Harris. London: Bodley Head, 1935.

Einstein, Albert. Vorwort/Foreword. Transl. Sonja Bargmann. Dialogue Concerning the Two Chief World Systems, Ptolemaic and Copernican. By Galileo Galilei. Transl. Stillman Drake. Berkeley: University of California Press, 1953. vi-xx.

Einstein, Albert. Relativity: The Special and the General Theory. Transl. Robert W. Lawson. London: Methuen, 1960.

Einstein, Albert. "Dialogue about Objections to the Theory of Relativity." The Berlin Years, Writings 1918-1921 (English translation supplement). The Collected Papers of Albert Einstein. Vol. 7. Transl. Alfred Engel. Princeton: Princeton Univeristy Press, 2002. 66-75.

Einstein, Albert. Über die spezielle und die allgemeine Relativitätstheorie. 24th ed. Berlin and Heidelberg: Springer, 2009 [1916].

Galilei, Galileo. Dialogue Concerning the Two Chief World Systems, Ptolemaic and Copernican. Transl. Stillman Drake. Berkeley: University of California Press, 1953.

Gaston, Bruce. "Brecht's Pastiche History Play: Renaissance Drama and Modernist Theatre in Leben Eduards des Zweiten von England.” German Life and Letters 56.4 (2003): 344-362.

Gerz, Raimund. "Tod des Cesare Malatesta." Prosa, Filme, Drehbücher. Ed. Jan Knopf. Stuttgart: Metzler, 2002. 54-59.

Gittig, Heinz. Illegale antifaschistische Tarnschriften, 1933-1945. Leipzig: Bibliographisches Institut, 1972.

Habermas, Jürgen. Structural Transformation of the Public Sphere: An Inquiry into a Category of Bourgeois Society. Transl. Thomas Burger. Cambridge, MA: MIT Press, 1991.

Hentschel, Klaus. Interpretationen und Fehlinterpretationen der speziellen und der allgemeinen Relativitätstheorie durch Zeitgenossen Albert Einsteins. Basel: Birkhäuser, 1990.

Hobsbawm, Eric. Introduction. The Communist Manifesto: A Modern Edition. By Karl Marx and Frederick Engels. London: Verso, 1998.

Musil, Robert. “Polygon der möglichen Meinungen.” Selbstkommentare aus dem Nachlass. Eds. Walter Fanta, Klaus Amann, and Karl Corino. Klagenfurt: Robert Musil-Institut der Universität Klagenfurt. DVD-Version 2009.

Pfanner, Helmut F. "Döblin, the Critic of Western Civilisation: The Amazon Trilogy." A Companion to the Works of Alfred Döblin. Eds. Roland Dollinger, Wulf Koepke, and Heidi Thomann Tewarson. Rochester: Camden House, 2003. 193-214.

Uekermann, Gerd. Renaissancismus und Fin de siècle: Die italienische Renaissance in der deutschen Dramatik der letzten Jahrhundertwende. Berlin and New York: De Gruyter, 1985.

Wizisla, Erdmut. "Vortreffliches für die verbildeten Zeitgenossen: Einstein schreibt Brecht über Galilei.” Albert Einstein - Ingenieur des Universums. Ed. Jürgen Renn. Vol. 3. Weinheim: Wiley-VCH, 2005. 350-353. 
